\title{
RUSSELL, BERKELEY, Y LA MATERIA OBJETIVA
}

ERNESTO SOSA

Brown University

Hay un supuesto que comparten Russell y Berkeley, uno de los supuestos que los coloca a ambos en la tradición empírica británica. Para Russell este supuesto toma la forma de su Principio del Conocimiento: ${ }^{1}$

Cada proposición que podemos entender tiene que estar compuesta de elementos cada uno de los cuales conocemos directamente.

“... Conocemos directamente cualquier cosa de la cual tenemos conciencia directa, sin mediación de ningún proceso de inferencia ni ningún conocimiento de verdades." ${ }^{2}$ A través de la sensación conocemos los datos de sensación, a través de la introspección conocemos los pensamientos, sentimientos, deseos, etcétera, y a través de la memoria conocemos las cosas que hemos conocido a través de la sensación o de la introspección. Además, a través de la concepción conocemos directamente los conceptos o universales, como la blancura, la diversidad, la hermandad, etcétera. Finalmente, cada uno probablemente se conoce directamente a sí mismo a través de la introspección. ${ }^{3}$

Partiendo de similares supuestos, Berkeley concluyó lo siguiente:

(M) La supuesta noción de la materia objetiva está desprovista de significado.

1 Bertrand Russell, The Problems of Philosophy, Londres, 1912.

2 Ibid., p. 46.

3 Ibid., pp. 51-52. 
Consideremos el siguiente razonamiento, con tres premisas y una conclusión:

(a) El principio del conocimiento. (Cada proposición que podemos entender tiene que estar compuesta de elementos cada uno de los cuales conocemos directamente).

(b) Uno no puede conocer directamente ninguna mesa (objetiva, material) en sí misma.

(c) Los elementos de la proposición de que la mesa ante uno (una cierta mesa objetiva y material) es rectangular son la mesa misma y la calidad de rectangular.

(d) Por lo tanto, no podemos entender la proposición de que la mesa ante uno (objetiva y material) es rectangular.

Al parecer Russell está comprometido a aceptar la conclusión de Berkeley $(M)$ si no puede evadir por lo menos una de las premisas $a, b$, o $c$. En The Problems of Philosophy Russell definitivamente quiere rechazar la conclusión $d$ y con ella el principio de Berkeley $(M)$. La premisa que rechaza es la $c$. Russell puede rechazar esta premisa en virtud de su Teoría de las Descripciones, la cual consideramos a continuación.

Con relación al esquema $(E)$ 'La cosa que tiene la propiedad $F$ tiene la propiedad $G$ ', Russell mantiene que muchas de sus instancias equivalen a una conjunción de tres proposiciones correspondientes:

(i) Hay por lo menos una cosa con la propiedad $\boldsymbol{F}$.

(ii) Hay cuando más una cosa con la propiedad $\boldsymbol{F}$.

(iii) Nada tiene la propiedad $F$ sin tener la propiedad $G$.

En particular, la proposición $(P)$ de que la cosa que tiene la propiedad de ser una mesa ante uno tiene la propiedad de ser rectangular equivale a la conjunción de tres proposiciones: 
(i) Hay por lo menos una cosa con la propiedad de ser una mesa ante uno.

(ii) Hay cuando más una cosa con la propiedad de ser una mesa ante uno.

(iii) Nada tiene la propiedad de ser una mesa ante uno sin tener la propiedad de ser rectangular.

Pero si la proposición $P$ realmente equivale a la conjunción de (i), (ii), y (iii), entonces parece ser un error suponer que la mesa (objetiva, material) misma ante uno sea un elemento de la proposición $P$. Parece errónea esta suposición pues entre los elementos de las proposiciones (i), (ii), y (iii) no se encuentra la mesa ante uno. Los elementos de estas proposiciones son ciertas propiedades o relaciones, por un lado, y uno mismo por el otro. La conjunción de estas proposiciones (i), (ii), y (iii) - y, por consiguiente la proposición $P$ - tiene como tema o sujeto la mesa ante uno "indirectamente", podríamos decir, en virtud del hecho de que este es el único objeto que llena los requisitos de las proposiciones (i) y (ii). El resultado de este razonamiento es que podemos ahora rechazar la premisa $c$ y por lo tanto evadir la indeseable conclusión $d$.

De inmediato surge un nuevo problema: ¿Puede uno conocer directamente la propiedad (que algo pueda tener) de ser una mesa ante uno? Pues de no ser así nuestro avance ha sido un engaño y Russell permanece comprometido a aceptar la conclusión $d$. Ahora el argumento sería éste:

(a) El principio del conocimiento.

(b') Uno no puede conocer la propiedad (que pueda tener algo) de ser una mesa (objetiva, material).

$\left(c^{\prime}\right)$ Entre los elementos de la proposición de que la mesa ante uno es rectangular está la propiedad de ser una mesa.

(d) Por lo tanto, no podemos entender la proposición de que la mesa ante uno es rectangular.

En el capítulo X Russell trata sobre nuestro conocimiento 
de propiedades o universales. Desafortunadamente, no se puede encontrar en este capítulo una respuesta firme a la pregunta si podemos o no conocer propiedades como la de ser una mesa. Es más, nos dice Russell que "... no parece haber ningún principio que nos permita decidir cuáles propiedades se pueden conocer directamente, pero parece claro que entre aquellas que si se pueden conocer directamente están las cualidades sensibles, las relaciones de espacio o tiempo, la semejanza y ciertas propiedades lógicas abstractas".. Puesto que la propiedad de ser una mesa no cae en ninguna de estas categorías que, según Russell, contienen las propiedades que con seguridad conocemos directamente, es sin duda razonable suponer que Russell por lo menos no estaba seguro de que conozcamos esa propiedad directamente. Por consiguiente él no puede haber estado seguro que $b$ ' fuera falsa. Luego entonces, ¿cómo puede él haber estado seguro que $d$ fuese falsa?

La clave de la solución se encuentra en la página 58 , donde encontramos que muchos "... universales como muchas entidades particulares, son conocidos sólo por descripción. Pero aquí, como en el caso de los entes particulares, el conocimiento acerca de lo que conocemos sólo por deseripción es reducible finalmente al conocimiento acerca de lo que se conoce directamente".

Berkeley también había supuesto que si pudiésemos encontrar una relación clara entre (el concepto de) la materia y nuestras ideas de los colores, las formas, etcétera (es decir, entre la materia y nuestras sensaciones de color, forma, etcétera), entonces sí podríamos entender la noción de la materia. Pero si se nos dice que la materia de una bola de nieve "sostiene" la blancura, redondez, etcétera, que vemos, esto no nos da tal relación clara. Pues el "sostén" no es aquel que unas columnas le dan a un techo. Pero entonces ¿qué clase de "sostén" es este?

La respuesta de Russell puede ser colegida de sus capítu.

4 Ibid., p. 109.

- Ibid., p. 58. 
los II y III, según creo yo, y es que el "sostén" es la casualidad. Así la propiedad de ser una mesa objetiva, material, es según Russell la propiedad tal que cuando un objeto con cierta relación espacio-temporal a uno tiene esa propiedad, esto causa en uno ciertas sensaciones visuales, del tacto, etcétera. Aquí se hace referencia sólo a la causalidad, a ciertos tipos de cualidades de nuestras sensaciones (aquellas que se requieren para tener uno una experiencia como si viese o to. case una mesa), y a ciertas relaciones de espacio o tiempo. Como hemos visto, para Russell todos éstos son universales que conocemos directamente, con la excepción de la causa. lidad. Pero entonces, ¿cómo llegamos a entender la causalidad, si no la conocemos directamente? La respuesta de Russell se puede colegir de su famoso ensayo "On the Notion of Cause" (que fue su discurso presidencial a la Aristotelian Saciety en el año cuando se publicó The Problems of Philosophy, 1912). Según ese ensayo en la medida que hay algo claro y útil en la noción común o filosófica de causalidad, es tan sólo la noción de ley de la naturaleza o ley científica, y esto envuelve nada más que ciertas "relaciones funcionales entre ciertos eventos en ciertas ocasiones, que llamamos determinantes, y otros eventos que ocurren antes o después o al mismo tiempo". Presumiblemente, estas relaciones funcionales envuelven sólo relaciones de espacio o tiempo y se recordará que éstas se encuentran entre los universales que para Russell conocemos directamente. Así vemos cómo Rus. sell puede aceptar el credo empirista (el principio del conocimiento) al mismo tiempo que rechaza el profundo agnos* ticismo de un Berkeley $(M)$.

- El artículo apareció primero en los Proceedings of the Aristotelian Society de 1912, pero ha sido reproducido en muchas antologías y colecciones. Mi cita es de Mystioism and Logic, del propio Russell, p. 201. 
The problem discussed in the paper is how Russell can avoid reaching the conclusion that the notion of objective matter is meaningless without rejecting his Principle of Knowledge. Berkeley accepted a similar principle and could not avoid that conclusion. The principle of knowledge says that

(a) "Every proposition which we can understand must be composed wholly of constituents with which we are acquainted."

And "we shall say that we have acquaintance with anything of which we are directly aware, without the intermediary of any process of inference or any knowledge of truths."

Russell would have to admit the conclusion if he accepted the following propositions (that seem obvious):

(b) One cannot be acquainted with any (objective, material) table in itself.

(c) The constituents of the proposition $P$, namely that the table before me (a certain objective and material table) is rectangular, are the table itself and the quality of being rectangular.

Here the conclusion would be that

(d) We cannot understand $P$.

But a similar argument can be made about every proposition that is about a material object.

Russell's way out consists in denying (c). Fortunately his theory of descriptions provides a different analysis of $P$. What the proposition means is really the following conjunction:

(i) There is at least one thing that has the property of being the table before me.

(ii) There is at most one thing that has the property of being the table before me.

(iii) Nothing has the property of being the table before me without having the property of being rectangular.

So, $(c)$ is false since the table before me is not a constituent of $P$. The constituents of $P$ are certain properties and relations and oneself. Now the problem is that if we are acquainted with ourselves and other properties and relations, Russell cannot be sure that we can be acquainted with the property of being a table.

The key to the solution of this problem is to be found in Chapter $\mathrm{X}$ of.The Problems of Philosophy where. Russell says "Many universals, like many: particulars, are only known to us by description. But here, as in the case of particulars, knowledge concerning what:is known 
by description is ultimately reducible to knowledge concerning what is known by acquaintance".

Berkeley had also admitted that if we could find a clear relation between (the notion of) matter and our ideas of colours, forms, etc., we could then understand the notion of matter. The idea that matter holds those qualities doesn't seem to mean anything.

Russell, as we gather from Chapters II and III, thinks that this relation is causality. Matter, with its properties, causes the relevant sensations in us. We are acquainted with the effect, but are we acquainfed with the notion of cause? Russell's answer is that what is useful in the notion of cause involves only functional relations between events, and these functional relations can be known by acquaintance since they are presumably relations of space and time.

Summary by Hugo Margáin 